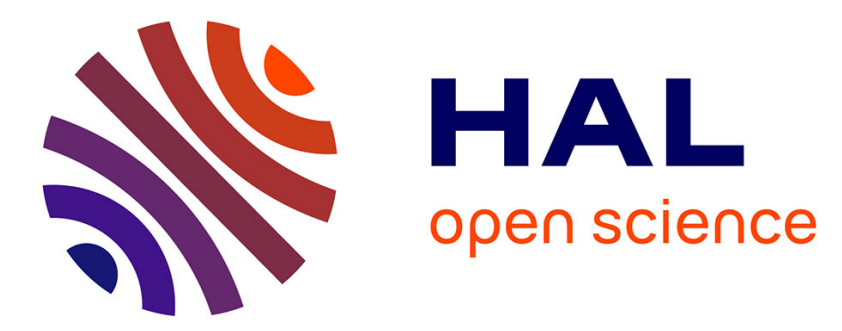

\title{
Diffraction of neon by a (117) copper surface
}

\author{
J. Lapujoulade, Y. Le Cruër, M. Lefort, Y. Lejay, E. Maurel, N. Papanicolaou
}

\section{To cite this version:}

J. Lapujoulade, Y. Le Cruër, M. Lefort, Y. Lejay, E. Maurel, et al.. Diffraction of neon by a (117) copper surface. Journal de Physique Lettres, 1981, 42 (21), pp.463-464. 10.1051/jphyslet:019810042021046300 . jpa-00231977

\section{HAL Id: jpa-00231977 https://hal.science/jpa-00231977}

Submitted on 1 Jan 1981

HAL is a multi-disciplinary open access archive for the deposit and dissemination of scientific research documents, whether they are published or not. The documents may come from teaching and research institutions in France or abroad, or from public or private research centers.
L'archive ouverte pluridisciplinaire HAL, est destinée au dépôt et à la diffusion de documents scientifiques de niveau recherche, publiés ou non, émanant des établissements d'enseignement et de recherche français ou étrangers, des laboratoires publics ou privés. 


\title{
Diffraction of neon by a (117) copper surface $\left({ }^{*}\right)$
}

\author{
J. Lapujoulade, Y. Le Cruër, M. Lefort, Y. Lejay, E. Maurel and N. Papanicolaou \\ Service de Physique Atomique, CEN de Saclay, 91191 Gif sur Yvette Cedex, France
}

(Reçu le 17 juin 1981, accepté le 18 septembre 1981)

\begin{abstract}
Résumé. - On a déterminé expérimentalement la figure de diffraction d'un faisceau d'atomes de néon d'énergie thermique par une surface vicinale de cuivre (117).

Cette figure de diffraction correspond bien au réseau formé par les marches atomiques equidistantes qui caractéri-
\end{abstract} sent cette surface.

\begin{abstract}
The diffraction pattern of a thermal beam of neon atoms by a (117) copper surface has been experimentally determined. This pattern is produced by the step lattice which characterizes the (117) face.
\end{abstract}

Since the pioneering work of Estermann and Stern [1] in 1930 the diffraction of atoms by various crystal surfaces has been many times observed which proves, if still necessary, the reality of waves associated with atomic beams. However these experiments were restricted to light atoms $(\mathrm{He}, \mathrm{H})$ or molecules $\left(\mathrm{H}^{2}, \mathrm{D}^{2}\right)$. It is only more recently that Boato et al. [2] have unambiguously shown the diffraction of a more complex atom like neon from lithium fluoride. Mason and Williams [3] have observed a weak diffraction peak for $\mathrm{Ne}$ on $\mathrm{Cu}(100)$ but it is not clear if this peak is due to the clean surface or to an impurity superlattice.

In this letter we present some experimental results which show that neon can also diffract from metallic crystals. This can help to a better understanding of the gas surface potential and surface structure. For this purpose we have used a copper single crystal which was cut along the (117) face. Figure 1 shows the structure of such a face. It is built from (100) terraces bounded by monoatomic steps. The experimental

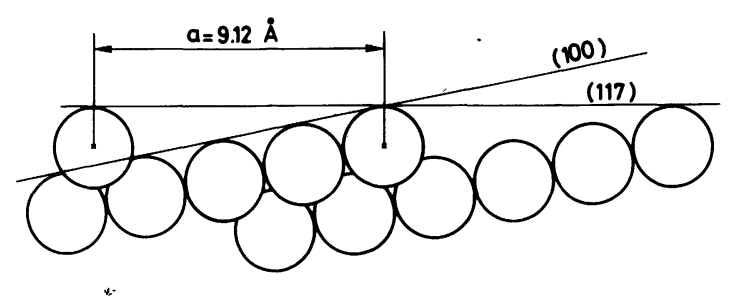

Fig. 1. - Atomic structure of $\mathrm{Cu}(117)$.

(*) La version française de cet article a été proposée pour publication aux Comptes Rendus de l'Académie des Sciences. set-up is the same that was used for a study of helium diffraction from the same crystal surface [4]. The crystal is placed in an ultra-high vacuum chamber.

It is cleaned in situ by a standard technique of $\mathrm{Ar}^{+}$ ion-bombardment followed by annealing at $773 \mathrm{~K}$. The incident neon beam is produced through a nozzle. The average beam energy is $E=63 \mathrm{meV}$ and the energy distribution is narrow enough. In these conditions the wave length is $\lambda=0.255 \AA$. The scattered atoms are collected into an ionization detector which can be moved in the incidence plane. The crystal is cooled down to $80 \mathrm{~K}$ in order to decrease the inelastic scattering (Debye-Waller factor).

.For a $60^{\circ}$ incidence with respect to the normal the diffraction pattern shown on figure 2 is obtained. Sharp diffraction peaks are clearly seen and are well resolved until 11th order. These peaks are superimposed to a more diffuse background which should

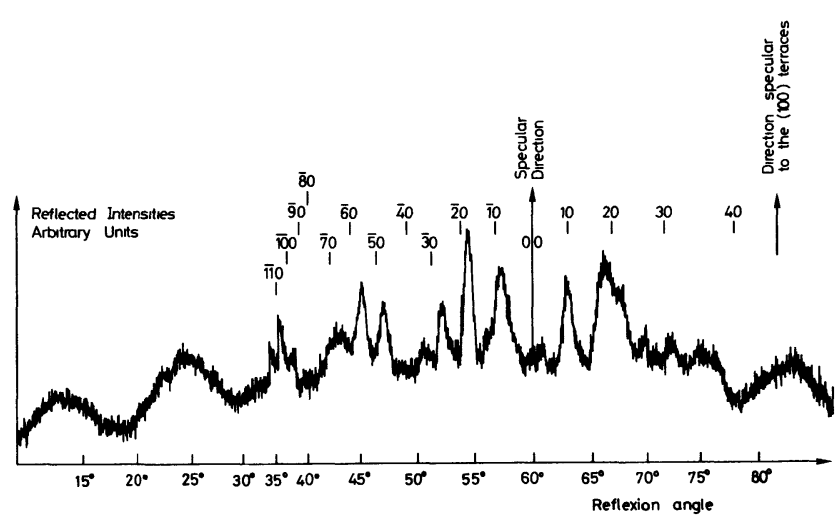

Fig. 2. - Neon diffraction by $\mathrm{Cu}(117)$; note that the abscissa scale is not linear. 
be attributed to inelastic scattering. The peak position marks were calculated from the Bragg relation

$$
\sin \theta_{\mathrm{r}}=\sin \theta_{\mathrm{i}} \pm m \frac{G}{|k|}
$$

$\theta_{\mathrm{r}}=$ reflexion angle

$\theta_{\mathrm{i}}=$ incidence angle,

$G=\frac{2 \pi}{a}, a:$ unit mesh of the step lattice,

$k=\frac{2 \pi}{\lambda}, \mathbf{k}:$ wave vector,

$n=$ diffraction peak index.

Discrepancies with experimental peaks position are certainly due to inaccuracies in the measurement of incident beam parameters $\left(\lambda, \theta_{\mathrm{i}}\right)$. The peak width corresponds well to the instrumental width given by the energy distribution in the beam, its angular aperture and the detector aperture.
The neon diffraction pattern is quite different from the helium one. Indeed, with helium, the diffraction peaks envelope fits well the rainbow shape given by step and terrace profile. With neon this no longer occurs and more precisely we do not observe strong peaks in the vicinity of the direction specular to the terraces. This behaviour is in contrast with the strong rainbow structure found on $\mathrm{Ne}-\mathrm{LiF}$ by Boato et al. Indeed the present result is quite unexpected since the wave length is shorter for neon than for helium which would bring about a more classical behaviour. However it should be emphasized that the interaction potential may be significantly different for helium and for neon. Especially the well depth is likely much deeper for neon than for helium.

Acknowledgments. - We thank Prof. Kastler for his interest in this work.

\section{References}

[1] Estermann, I., Stern, O., Z. Phys. 61 (1930) 95.

[2] Boato, G., Cantini, P., Mattera, L., Surf. Sci. 55 (1976) 141.

[3] Williams, B. F., Williams, B. R., Surf. Sci. 75 (1976) L-786.
[4] Lapujoulade, J., Lejay, Y., Papanicolaou, N., Surf. Sci. 90 (1979) 133. 